\title{
Industry-University-Research Interaction Model for Teaching Quality Evaluation of Economic Management Courses
}

\author{
https://doi.org/10.3991/ijet.v16i23.27833 \\ Yang Xiao ${ }^{1}$, Xijun Zhang ${ }^{1}$, Shengnan Ren ${ }^{1}$, Hongyun $\mathrm{Li}^{2}{ }^{(凶)}$ \\ ${ }^{1}$ Shijiazhuang University of Applied Technology, Shijiazhuang, China \\ ${ }^{2}$ Shijiazhuang Information Engineering Vocational College, Shijiazhuang, China \\ xiaoyangesjzpt.edu.cn
}

\begin{abstract}
Teaching quality evaluation is an important means of colleges to control teaching quality, and expedite teachers to keep improving teaching levels. Based on industry-university-research interaction (IURI) model, this paper surveys the current state of teaching quality evaluation of college teachers, establishes the indices for teaching quality evaluation of economic management courses, and presents a few countermeasures for improving teaching quality evaluation. The results show that: teaching quality evaluation covers three types of data: student evaluation, supervisor evaluation, and network-assisted teaching evaluation. Our student evaluation index system covers four dimensions: teaching attitude, teaching content, teaching method, and teaching effect. Our expert evaluation index system also covers four dimensions: teaching preparation, teaching ability, teaching management, and teaching effect. Our multi-subject teaching quality evaluation system for economic management courses covers four modules: student module, teacher module, supervisor module, and administrator module. This research lays a theoretical basis for applying the IURI model in teaching reform.
\end{abstract}

Keywords - teaching quality, teaching level, industry-university-research interaction (IURI) model, economic management, multi-subject evaluation system

\section{$1 \quad$ Introduction}

Teaching quality is the lifeline for higher educational schools [1]. To improve the quality of higher education, optimizing the teaching quality of colleges and universities is the primary task, and the teaching quality evaluation of college teachers is an important means of teaching quality improvement [2, 3]. At present, with the continuous reform of the educational system, higher requirements have been imposed on the teaching quality of higher education. In terms of teaching quality evaluation, some policies have been adjusted, and multi-subject and multi-angle evaluation modes have been introduced to the teaching quality evaluation system [4, 5]. After constant practice and optimization of the existing effective evaluation systems, most colleges and universities 
in China have not established teaching quality evaluation systems that are suitable for their respective conditions $[6,7]$.

For the development of higher education, the key issue has been shifted from quantitative growth to quality improvement. Quality improvement has become a consensus in the educational circle, and a core task of higher education reform in China $[8,9]$. The evaluation of the teaching quality of college teachers is an important means to improve the quality of higher education $[10,11]$. Seeing from a realistic point of view, teaching quality evaluation is an indispensable work for every school. The workload of teaching quality evaluation is heavy and the work type is complex and diverse; by researching the status quo of teaching quality evaluation work in colleges and universities and conducting in-depth discussion, contradictions and problems in teaching evaluation could be resolved $[12,13]$. Teaching quality evaluation is the process of judging the value of teaching activities and teaching effect using feasible evaluation techniques and methods based on certain teaching goals, it judges not only the teaching ability of teachers and their teaching effect, but also the learning ability of students and their learning effect [14-16].

The IURI model includes the evolution of learning-industry structure, and the interaction among the hierarchical structure of industry layout-education, the structure of education disciplines, and the structure of education layout $[17,18]$. In the current teaching quality evaluation in China, the evaluation subject selection tends to change from a single evaluation subject to multiple evaluation subjects $[19,20]$. Some colleges and universities monitor the classroom teaching to ensure good teaching effect, hoping to improve from multiple aspects such as education decision formulation, teaching management standardization, and teaching quality evaluation. In terms of teaching management standardization, teaching quality valuation has played a very important role in promoting teaching reform, monitoring teaching process, enhancing teacher competency, and improving teaching quality [21]. Based on the IURI model, this study surveyed the status quo of teaching quality evaluation in colleges and universities, established a few indices for teaching quality evaluation of economic management courses, and presented some countermeasures for improving teaching quality evaluation.

\section{The status quo of teaching quality evaluation in colleges and universities}

\subsection{Analysis of the status quo}

Teaching quality evaluation is an organized and planned system formed by the combinations of evaluation criteria, evaluation methods, and various evaluation indices used by teaching quality evaluators $[22,23]$. The teaching quality evaluation system stipulates the scope, content, and scale of the evaluation, providing a basis for the evaluation of teaching quality $[24,25]$. Teaching indices mainly examine the specific works done by teachers in teaching $[26,27]$. In order to improve teaching level and quality, figure out the teaching situation of teachers in each department, and motivate teachers' 
work enthusiasm, Guangzhou University conducted a questionnaire survey to study the teaching quality evaluation system in the school, and helped teachers perform correct teaching behaviors that are conducive to realizing the teaching goals [28, 29].

There are many indices that can reflect the teaching quality of teachers. Through survey, five most important ones were selected, as shown in Figure 1, among these indices, the most important one is professional knowledge, followed by teaching attitude, professional ethics, scientific research ability, and teaching experience. Survey results of multiple higher educational schools showed that their teaching quality evaluation included three parts: student evaluation, supervisor evaluation, and network-assisted evaluation [30]. Figure 2 is a flow chart of students' online teaching evaluation. The entire process is organized and promoted by the college, teachers and students are encouraged to participate actively, students log in to the teaching evaluation system to score the teaching two weeks before the final exam, the teaching affairs office summarizes and counts the online evaluation information, analyzes and diagnoses teachers' teaching situations, writes teaching evaluation reports, the results are adopted for the evaluation of teachers' teaching quality. The teaching evaluation reports are submitted to the college, then the college formulates rectification measures according to the feedback opinions, and helps and guides teachers to improve their teaching level.

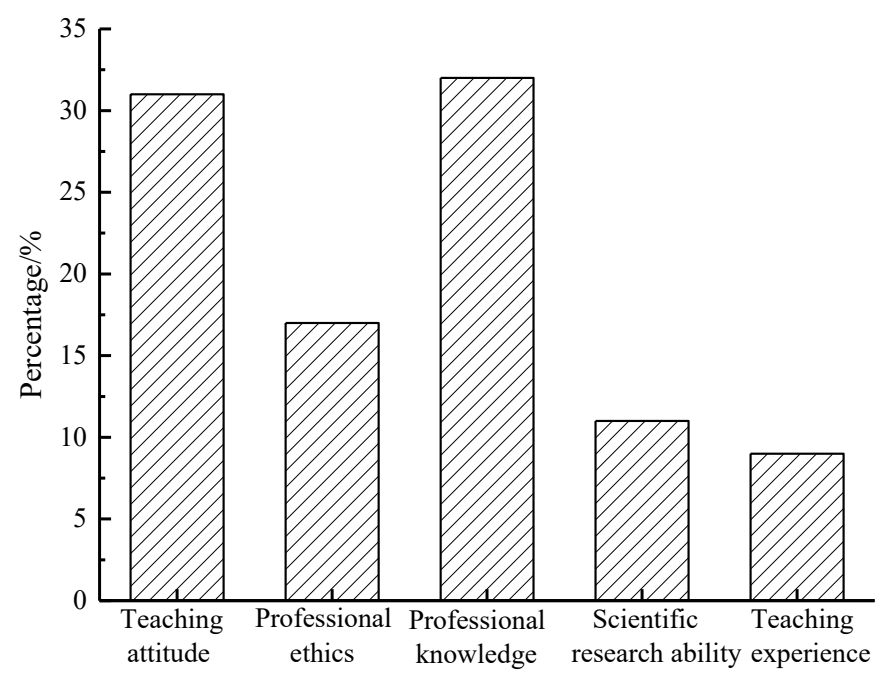

Fig. 1. Indices that can reflect the teaching quality of teachers 


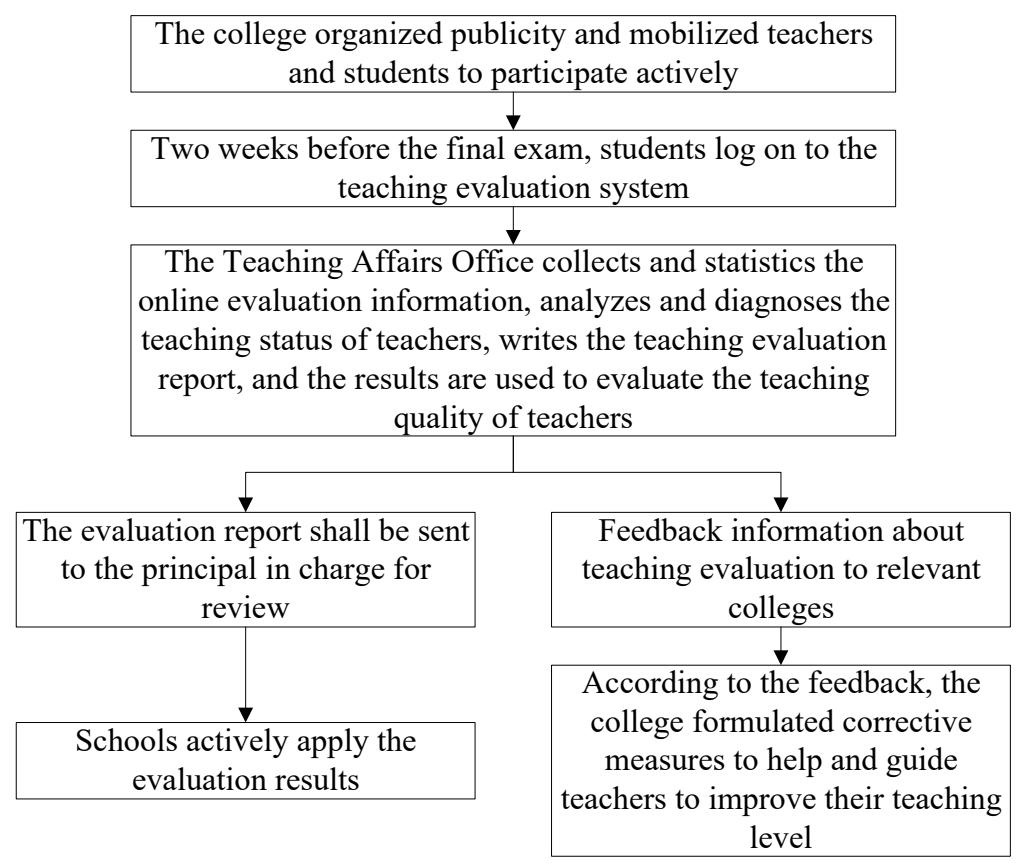

Fig. 2. Flow chart of students' online teaching evaluation

\subsection{Problems in teaching quality evaluation}

Currently, the teaching quality evaluation of college and universities are generally divided into four grades: excellent, good, qualified, and unqualified [31, 32]. According to the survey, the teaching quality evaluation of economic management courses has a few problems, as shown in Figure 3, from students' perspective, they do not have a thorough understanding of the purpose and significance of the teaching evaluation activity; their understanding of the specific content of teaching quality evaluation is insufficient; most students consider teaching evaluation as an unnecessary job, they generally think arranging the evaluation time in the semester end is inappropriate, and they do not have the willingness to know about the teaching evaluation results. From teachers' perspective, most teachers think teaching quality evaluation is unnecessary; teaching evaluation restricts teachers' teaching activities; the feedback results of teaching quality evaluation are too simple; teachers have doubts about the objectivity of the evaluation results; and they believe that the teaching evaluation system needs improvement. Figure 4 shows the reasons for the implementation problems of teaching quality evaluation. At first, the promotion work and training of students' teaching evaluation are insufficient; second, the work focus of supervisors' teaching evaluation has not been completely shifted yet; third, there's a teacher-student game in teaching quality evaluation; fourth, emphasizing on summative evaluation while ignoring formative evaluation; fifth, there is a managerialist tendency in teaching quality evaluation; sixth, there 
is a contradiction between the disclosure of evaluation results and the protection of teachers' privacy.

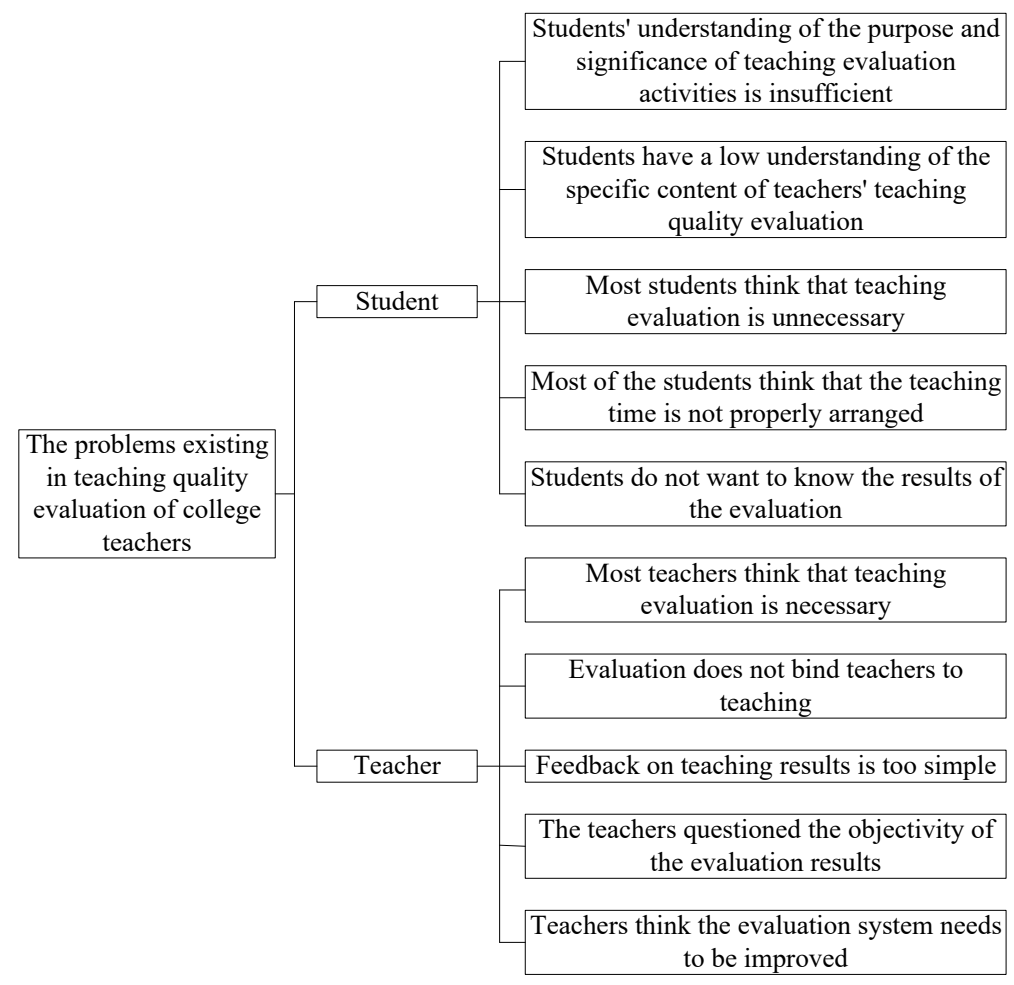

Fig. 3. Problems existing in teaching quality evaluation of college teachers

\begin{tabular}{|c|c|}
\hline $\begin{array}{c}\text { Insufficient publicity and training of } \\
\text { evaluation and teaching }\end{array}$ \\
\hline $\begin{array}{c}\text { The causes of the } \\
\text { implementation of } \\
\text { teaching quality } \\
\text { evaluation }\end{array}$ \\
\hline not completely shifted
\end{tabular}

Fig. 4. The causes of implementation problems in teaching quality evaluation 


\section{Design of indices of teaching quality evaluation based on the IURI model}

\subsection{Design of indices of teaching quality evaluation of economic management courses}

In the context of industry-university-research integration, the teaching quality evaluation of economic management courses needs to pay attention to the characteristics of the discipline or the college, and establishes an effective teaching evaluation index system with multiple evaluation subjects $[33,34]$. Figure 5 shows the principles of constructing a multi-subject teaching quality evaluation system. The system construction needs to follow the principles of discipline-industry matching, skill-position matching, teaching-education matching, and teaching-student matching. Students' teaching evaluation is based on their subjective feelings. Figure 6 shows the proposed student teaching evaluation index system, which contains four dimensions of teaching attitude, teaching content, teaching method, and teaching effect. In terms of teaching attitude, teachers are required to be rigorous, spirited, and responsible in teaching. In terms of teaching content, teachers are required to be fully prepared before class, the content structure should be clear, and the key points and difficult points should be highlighted. In terms of teaching method, teachers are required to have good lecturing skills and language expression ability, and they should be able to interact with students smoothly. In terms of teaching effect, teachers are required to be able to let students understand the lecturing content, increase students' interest in the course, and enhance their problem-solving ability. Figure 7 shows the proposed expert teaching evaluation index system, which evaluates from four dimensions of teaching preparation, teaching ability, teaching management, and teaching effect. The teaching preparation dimension mainly evaluates the teachers' teaching materials, syllabus, weekly calendars, and teaching plans; the teaching ability dimension mainly evaluates the teachers' teaching content, methods, and tools, etc.; the teaching management dimension mainly evaluates students' attendance rate, homework and assignment, and learning process management, etc.; the teaching effect dimension mainly evaluates the classroom atmosphere, students' classroom performance, and teachers' lecturing characteristics.

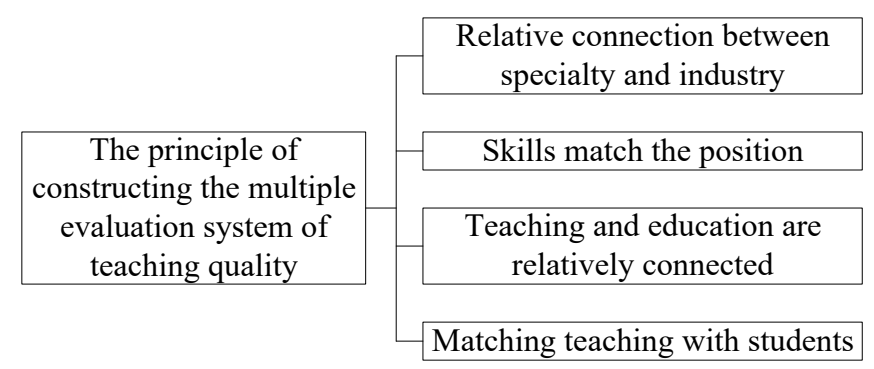

Fig. 5. Principles of constructing a multi-subject teaching quality evaluation system 


\begin{tabular}{|c|c|c|}
\hline \multirow{3}{*}{\begin{tabular}{|c|} 
\\
$\begin{array}{c}\text { Student evaluation } \\
\text { teaching index } \\
\text { system }\end{array}$ \\
\end{tabular}} & $\begin{array}{l}\text { Evaluation } \\
\text { indicators }\end{array}$ & Index connotation \\
\hline & $\begin{array}{l}\text { Teaching } \\
\text { attitude }\end{array}$ & $\begin{array}{l}\text { Teaching rigorous, class spirit full, serious and } \\
\text { complex }\end{array}$ \\
\hline & $\begin{array}{c}\text { Teaching } \\
\text { content }\end{array}$ & $\begin{array}{c}\text { Lesson preparation is sufficient, the context is clear, } \\
\text { the key and difficult points are explained clearly } \\
\text { The teaching content is substantial and moderate, } \\
\text { and the combination of theory and practice is } \\
\text { emphasized }\end{array}$ \\
\hline & $\begin{array}{l}\text { Teaching } \\
\text { method }\end{array}$ & $\begin{array}{l}\text { Good teaching skills and language skills, good } \\
\text { interaction with students }\end{array}$ \\
\hline & $\begin{array}{c}\text { Teaching } \\
\text { effect }\end{array}$ & $\begin{array}{l}\text { Can understand the content of the lecture, learning } \\
\text { method and problem solving ability is improved }\end{array}$ \\
\hline
\end{tabular}

Fig. 6. The proposed student teaching evaluation index system

\begin{tabular}{|c|c|c|}
\hline \multirow{4}{*}{$\begin{array}{l}\text { Expert evaluation } \\
\text { of teaching index } \\
\text { system }\end{array}$} & $\begin{array}{l}\text { Evaluation } \\
\text { indicators }\end{array}$ & Index connotation \\
\hline & $\begin{array}{l}\text { Teaching } \\
\text { preparation }\end{array}$ & $\begin{array}{l}\text { Teaching materials, syllabus, weekly } \\
\text { calendar and lesson plans, etc }\end{array}$ \\
\hline & Teaching ability & $\begin{array}{l}\text { Teaching content, teaching methods } \\
\text { and means, language expression, etc }\end{array}$ \\
\hline & \begin{tabular}{|c|} 
Teaching \\
management
\end{tabular} & $\begin{array}{l}\text { Classroom discipline, class order, } \\
\text { student attendance, homework and } \\
\text { learning process management, etc }\end{array}$ \\
\hline & Teaching effect & $\begin{array}{l}\text { Classroom atmosphere, student } \\
\text { attendance rate, teacher teaching } \\
\text { characteristics, etc }\end{array}$ \\
\hline
\end{tabular}

Fig. 7. The proposed expert teaching evaluation index system

\subsection{Construction of the multi-subject teaching quality evaluation system for economic management courses}

Chinese colleges and universities generally pay less attention to system operation, they fail to use scientific management method to make good use of the teaching evaluation results, and the teaching evaluation result feedback and improvement links are always missing. Figure 8 gives the workflow of teaching quality evaluation, steps included in the workflow are: formulate teaching evaluation plan; regularly enter the eval- 
uation data of evaluation subjects; back-stage data processing and statistics; send evaluation results to each department or the office of teaching affairs; each department talks to unqualified teachers.

Figure 9 lists the implementation effects of the teaching quality evaluation of economic management courses, including: first, a good atmosphere of "concentrating on teaching and education" has been created; teachers and students now are highly approved of teaching quality evaluation; with the establishment of the multi-subject teaching quality evaluation system, most teachers and students consider the implementation of teaching quality evaluation as a necessity, and it has a positive role in motivating teachers' teaching activities; it is helpful for improving teachers' personal abilities, according to the evaluation results, teachers can continuously optimize their knowledge framework, enrich teaching content, actively communicate with students, and understand their thoughts in a timely manner; it is helpful for selecting quality courses, in case of economic management courses, it helps to select and develop a series of excellent courses, and encourage teachers who get good results in teaching evaluation to open more courses.

Figure 10 shows the functions of the proposed multi-subject teaching quality evaluation system of economic management courses. Function modules of the system include four parts: student module, teacher module, supervisor module, and administrator module. Wherein the student module contains two aspects: personal information, and student's teaching evaluation; the teacher module contains: personal information, teacher's teaching evaluation, self-evaluation, and peer evaluation; the supervisor module contains personal information and supervisor's teaching evaluation; the administrator module contains: administrator information, evaluation theme management, evaluation database management, query and printing, etc.

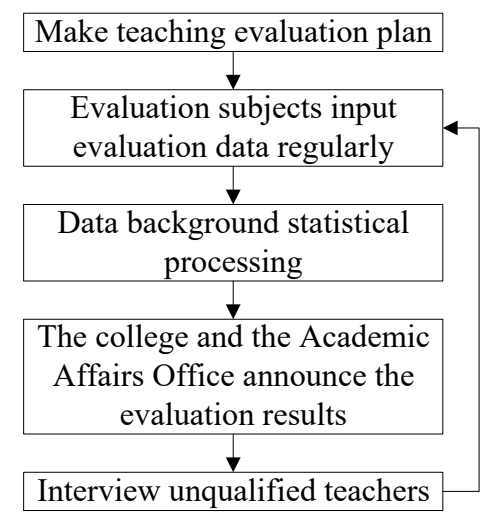

Fig. 8. The workflow of teaching quality evaluation 


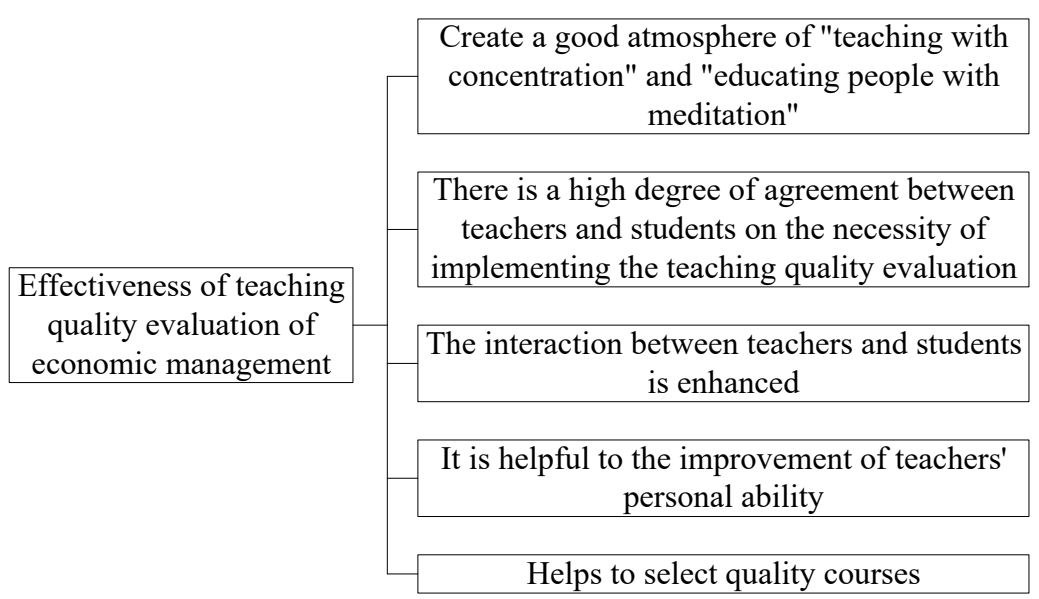

Fig. 9. Implementation effects of the teaching quality evaluation of economic management courses

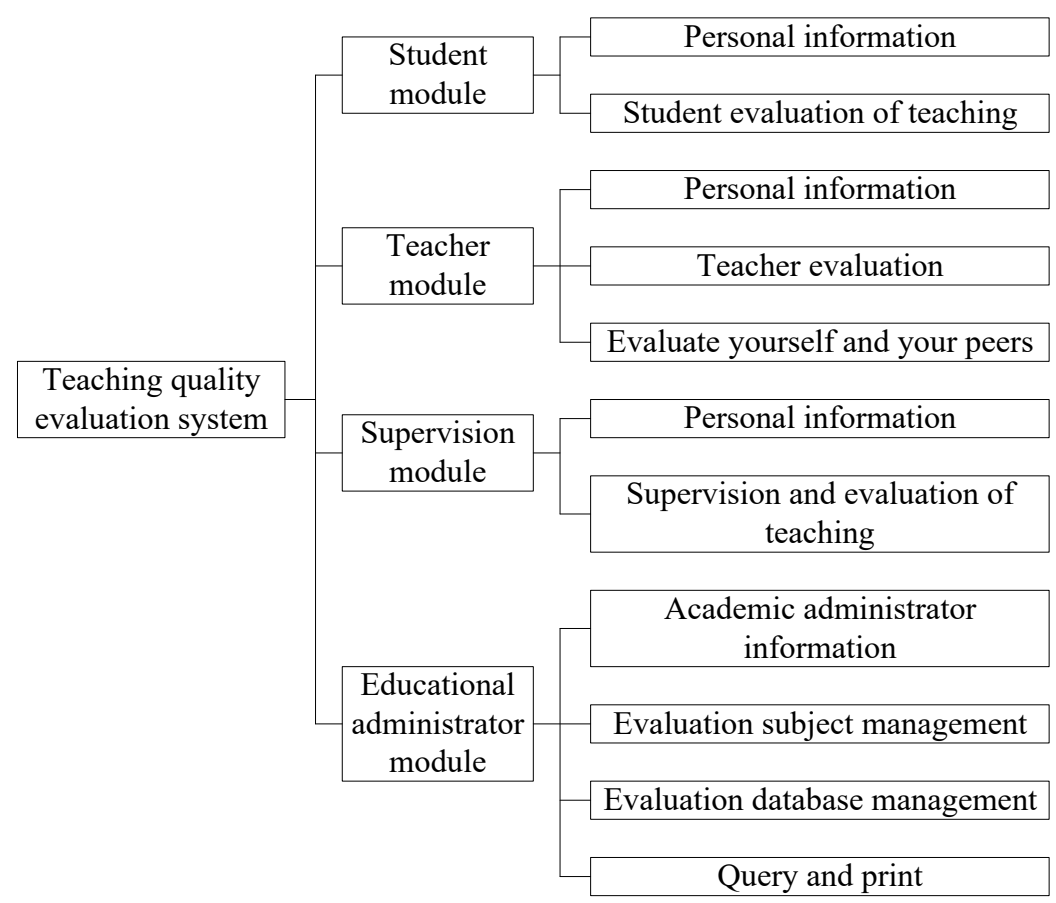

Fig. 10.Functions of the proposed multi-subject teaching quality evaluation system of economic management courses 


\section{Countermeasures to strengthen the teaching quality evaluation of economic management courses}

Above-mentioned survey revealed that there're many problems with the teaching quality evaluation of economic management courses, and colleges and universities have improved their corresponding teaching evaluation indices. Based on the IURI model, this paper proposed a few countermeasures for improving the teaching quality evaluation of economic management courses, as shown in Figure 11. First, a culture of teaching quality evaluation of college teachers should be created to enhance the understanding of teachers and students on the teaching quality evaluate work; second, close attention should be paid to the awareness of improvement; college administrators need to form an up-to-date understanding of teaching quality evaluation from the perspective of improvement, lay emphasis on how to make use of the evaluation results to find out misunderstandings and blind spots in the teaching work of teachers, and ensure that the teaching evaluation work not only can exert an effective impact on decision-making and management, but also can react on teaching quality, thereby enhancing teachers' teaching ability and providing students with better education. The process and utilization of teaching evaluation results should be optimized to better interpret and analyze the teaching quality evaluation results. The teaching evaluation time should be arranged reasonably; the traditional teacher-centered teaching evaluation method emphasizes too much on teaching content, tool, method, and attitude, although it regards students as the ultimate beneficiaries and takes the learning achievement of students as the orientation, from the evaluation results, we can't tell whether the teacher has triggered students' interest or not. Figuring out teacher's teaching quality from the perspective of student learning is conductive for teachers to judge students' real learning effect so that the teacher can adjust the teaching arrangement in a timely manner, in this way, students can be truly treated as the center of teaching quality evaluation, and the teaching quality can be improved continuously with teaching quality diagnosis as the tool. 


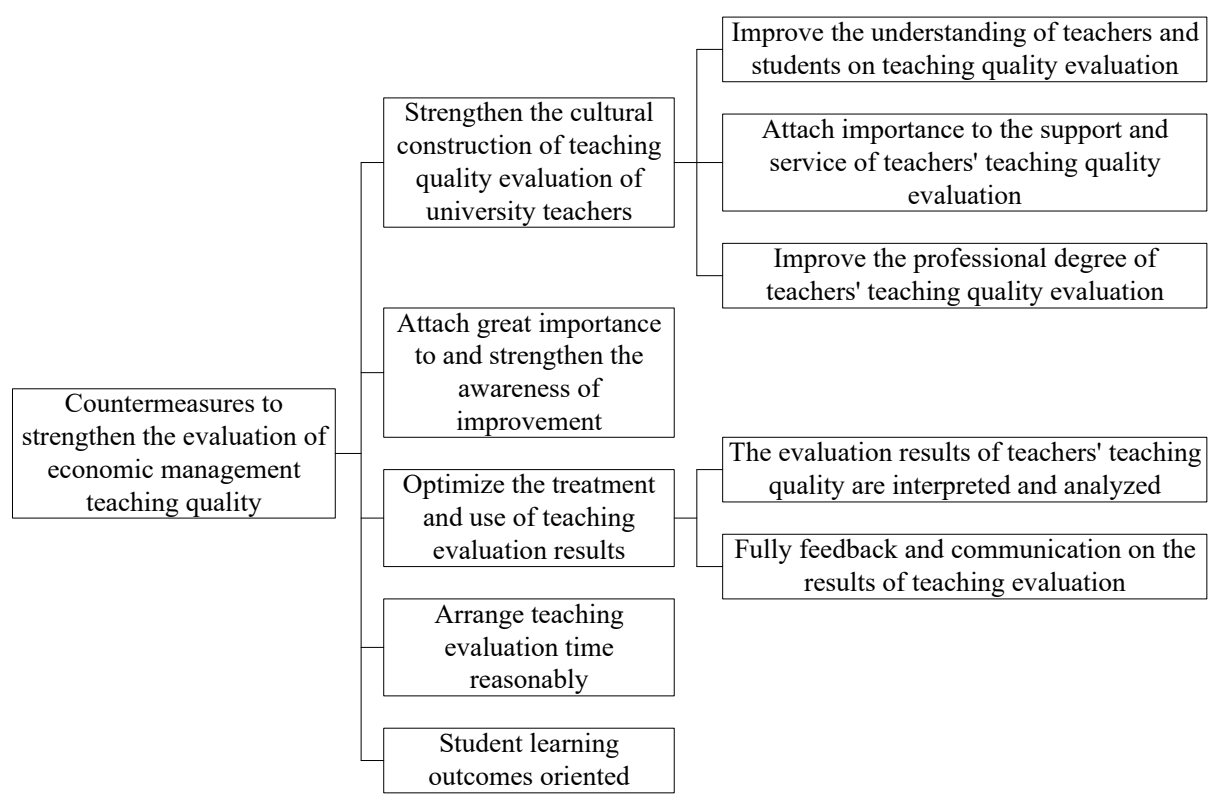

Fig. 11.Countermeasures for improving teaching quality evaluation of economic management courses

\section{Conclusion}

Based on the IURI model, this study surveyed the current state of teaching quality evaluation of college teachers, established indices for teaching quality evaluation of economic management courses, and gave a few countermeasures for improving teaching quality evaluation. The specific conclusions are as follows:

1. In the context of industry-university-research integration, the construction of teaching quality evaluation systems needs to follow the principles of discipline-industry matching, skill-position matching, teaching-education matching, and teaching-student matching.

2. With the establishment of the multi-subject teaching quality evaluation system, now most teachers and students believe that teaching quality evaluation is very necessary, which will play a positive role in motivating teachers' teaching activities and help them improve personal abilities, moreover, it can facilitate the selection of highquality courses.

3. Steps of teaching quality evaluation include: formulate teaching evaluation plan; regularly enter the evaluation data of evaluation subjects; back-stage data processing and statistics; send evaluation results to each department or the office of teaching affairs; each department talks to unqualified teachers. 


\section{References}

[1] Hammitt, J.K., Robinson, L.A. (2021). Introduction to special issue on risk assessment, economic evaluation, and decisions. Risk Analysis, 41(4): 559-564. https://doi.org/10. $\underline{1111 / \text { risa. } 13720}$

[2] Tóth, Z.E., Andor, G., Árva, G. (2017). Peer review of teaching at the Budapest university of technology and economics faculty of economic and social sciences. International Journal of Quality and Service Sciences, 9(3-4): 402-424. https://doi.org/10.1108/ijqss-02-2017$\underline{0014}$

[3] Abdullah, N.L., Hanafiah, M.H., Hashim, N.A. (2013). Developing creative teaching module: business simulation in teaching strategic management. International Education Studies, 6(6): 95-107. https://doi.org/10.5539/ies.v6n6p95

[4] Wei, L., Cao, S., Song, Y. (2014). The harmonization of professional teaching and professional-competency training in financial management. Chinese Studies, 3(4): 165-170. https://doi.org/10.4236/chnstd.2014.34023

[5] Mestry, R., Bodalina, K. (2015). The perceptions and experiences of school management teams and teachers of the management of physical resources in public schools. Educational Management Administration \& Leadership, 43(3): 433-451. https://doi.org/10.1177 11741143214549972

[6] Toth, Z.E., Jonas, T., Berces, R., Bedzsula, B. (2013). Course evaluation by importanceperformance analysis and improving actions at the Budapest university of technology and economics. International Journal of Quality \& Service Sciences, 5(1): 66-85. https://doi.org/10.1108/17566691311316257

[7] Meads, C., Davenport, C., Małysiak, S., Kowalska, M., Zapalska, A., Guest, P., MartinHirsch, P., Borowiack, E., Auguste, P., Barton, P., Roberts, T., Khan, K., Sundar, S. (2014). Evaluating pet-ct in the detection and management of recurrent cervical cancer: systematic reviews of diagnostic accuracy and subjective elicitation. BJOG, 121(4): 398-407. https://doi.org/10.1111/1471-0528.12488

[8] Chen, X. (2021). Design of a hybrid classroom teaching quality evaluation system based on information technology. Journal of Physics Conference Series, 1852(3): 032025. https://doi.org/10.1088/1742-6596/1852/3/032025

[9] Zhang, X., Wei, Z., Han, T. (2021). Php-based undergraduate data reporting and teaching quality evaluation information system. Journal of Physics Conference Series, 1827: 012174. https://doi.org/10.1088/1742-6596/1827/1/012174

[10] Guo, J., Yu, S. (2020). Evaluation model of college English teaching quality based on big data analysis. IOP Conference Series: Materials Science and Engineering, 750: 012077. https://doi.org/10.1088/1757-899x/750/1/012077

[11] Zhang, M., Yu, X. (2020). The construction of teaching quality evaluation system of modern apprenticeship based on big data. Journal of Physics Conference Series, 1578: 012124. https://doi.org/10.1088/1742-6596/1578/1/012124

[12] Jiao, Y. (2020). The application of artificial intelligence technology in the quality evaluation of dance multimedia teaching in higher vocational colleges. Journal of Physics: Conference Series, 1533(3): 032059. https://doi.org/10.1088/1742-6596/1533/3/032059

[13] Fauth, B., Wagner, W., Bertram, C., Gllner, R., Trautwein, U. (2019). Don't blame the teacher? the need to account for classroom characteristics in evaluations of teaching quality. Journal of Educational Psychology, 112(6): 1284-1302. https://doi.org/10.1037/edu0000416

[14] Zhang, L., Fu, H., Wan, N. (2018). Research on the application of AHP and fuzzy comprehensive evaluation of teaching quality in basic mathematics classroom. Creative Education, 9(15): 2615-2626. https://doi.org/10.4236/ce.2018.915197

[15] Fraile, R., Bosch-Morell, F. (2015). Considering teaching history and calculating confidence intervals in student evaluations of teaching quality. Higher Education, 70(1): 55-72. https://doi.org/10.1007/s10734-014-9823-0 
[16] Magen-Nagar, N., Azuly, D. (2016). The contribution of school climate and teaching quality to the improvement of learning achievements, according to an external evaluation system. Creative Education, 7(13): 1773-1784. https://doi.org/10.4236/ce.2016.713181

[17] Zenawi, Z., Jos, B., Willem, J.V. (2011). Conceptions and practices in teaching and learning: implications for the evaluation of teaching quality. Quality in Higher Education, 17(2): 151161. https://doi.org/10.1080/13538322.2011.582793

[18] Tchorz, J.P., Ganter, P.A., Woelber, J.P., Stampf, S., Hellwig, E., Altenburger, M.J. (2014). Evaluation of an improved endodontic teaching model: do preclinical exercises have an influence on the technical quality of root canal treatments? International Endodontic Journal, 47(5): 410-415. https://doi.org/10.1111/iej.12162

[19] Lewisson, N., Hellgren, L., Johansson, J. (2013). Quality improvement in clinical teaching through student evaluations of rotations and feedback to departments. Medical Teacher, 35(10): 820-825. https://doi.org/10.3109/0142159x.2013.802302

[20] Yu, D. (2013). Prioritized information fusion method for triangular intuitionistic fuzzy set and its application to teaching quality evaluation. International Journal of Intelligent Systems, 28(5): 411-435. https://doi.org/10.1002/int.21583

[21] Byrne, M., Flood, B. (2003). Assessing the teaching quality of accounting programmes: an evaluation of the course experience questionnaire. Assessment \& Evaluation in Higher Education, 28(2): 135-145. https://doi.org/10.1080/02602930301668

[22] Burns, S.M., Ludlow, L.H. (2005). Understanding student evaluations of teaching quality: the contributions of class attendance. Journal of Personnel Evaluation in Education, 18(2): 127-138. https://doi.org/10.1007/s11092-006-9002-7

[23] Iezzi, D.F. (2005). A method to measure the quality on teaching evaluation of the university system: the italian case. Social Indicators Research, 73(3): 459-477. https://doi.org/ 10.1007/s11205-005-2923-6

[24] Waithanji Ngware, M., Ndirangu, M. (2005). An improvement in instructional quality: can evaluation of teaching effectiveness make a difference?. Quality Assurance in Education, 13(3): 183-201. https://doi.org/10.1108/09684880510607936

[25] Arah, O.A., Heineman, M.J., Lombarts, K. (2012). Factors influencing residents' evaluations of clinical faculty member teaching qualities and role model status. Medical Education, 46(4): 381-389. https://doi.org/10.1111/j.1365-2923.2011.04176.x

[26] Hallinger, P. (2010). Using faculty evaluation to improve teaching quality: a longitudinal case study of higher education in southeast Asia. Educational Assessment Evaluation \& Accountability, 22(4): 253-274. https://doi.org/10.1007/s11092-010-9108-9

[27] Lin, X. (2019). Research on the industrial technology road-mapping based on the SECI model. Open Journal of Social Sciences, 7(4): 52-62. https://doi.org/10.4236/jss.2019.74005

[28] Blackmore, J. (2009). Academic pedagogies, quality logics and performative universities: evaluating teaching and what students want. Studies in Higher Education, 34(8): 857-872. https://doi.org/10.1080/03075070902898664

[29] Spooren, P., Mortelmans, D., Denekens, J. (2007). Student evaluation of teaching quality in higher education: development of an instrument based on 10 Likert-scales. Assessment \& Evaluation in Higher Education, 32(6): 667-679. https://doi.org/10.1080/026029 30601117191

[30] Mulready-Shick, J., Kafel, K.W., Banister, G., Mylott, L. (2009). Enhancing quality and safety competency development at the unit level: an initial evaluation of student learning and clinical teaching on dedicated education units. Journal of Nursing Education, 48(12): 716-9. https://doi.org/10.3928/01484834-20091113-11

[31] Chou, S.Y., Luo, J., Ramser, C. (2020). High-quality vs low-quality teaching: a text-mining study to understand student sentiments in public online teaching reviews. Journal of International Education in Business, 14(1): 93-108. https://doi.org/10.1108/jieb-01-2020-0007 
Paper-Industry-University-Research Interaction Model for Teaching Quality Evaluation of Economic...

[32] Stanny, C.J., Arruda, J.E. (2017). A comparison of student evaluations of teaching with online and paper-based administration. Scholarship of Teaching and Learning in Psychology, 3(3): 198-207. https://doi.org/10.1037/st10000087

[33] Oermann, M.H., Conklin, J.L., Sharron, R., Bush, M.A. (2018). Student evaluations of teaching (SET): Guidelines for their use. Nursing Forum, 53(3): 280-285. https://doi. org/10.1111/nuf.12249

[34] Kong, L., Xiao, L. (2018). Research on the interaction between producer services and manufacturing industry in Shaanxi province. American Journal of Industrial and Business Management, 8(5): 1277-1289. https://doi.org/10.4236/ajibm.2018.85087

\section{$7 \quad$ Authors}

Yang Xiao, graduated from Hebei University of Economics and Business in 2002, master of finance. She is a lecturer and works in Shijiazhuang University of Applied Technology. Her main research fields are economic management and higher vocational education (email: blue_bat@126.com).

Xijun Zhang, graduated from North China University of technology in 1994, master of engineering. She is a lecturer and works in Shijiazhuang University of Applied Technology. Her main research fields are business administration and higher vocational education (email: 2003110589@sjzpt.edu.cn).

Shengnan Ren, graduated from Southwest Jiaotong University in 2011, master of logistics engineering. She works in Shijiazhuang University of Applied Technology. Her main research field is logistics transportation management (email: 2013010661 @sjzpt.edu.cn).

Hongyun Li, graduated from Hebei University of Economics and Business in 2003, master of economics. She is an associate professor, and work in Shijiazhuang Information Engineering Vocational College. Her main research fields are economic management and higher vocational education.

Article submitted 2021-10-13. Resubmitted 2021-11-14. Final acceptance 2021-11-16. Final version published as submitted by the authors. 